\title{
FUNGSI TINDAK TUTUR DIREKTIF PEDAGANG ASONGAN PADA KAPAL MOTOR PENYEBERANGAN DI PELABUHAN ULEE LHEUE BANDA ACEH
}

\author{
Sakdiahı, Maulidya Cahyani1, Rahmad Nuthihar3 \\ ${ }_{1}$ Universitas Abulyatama \\ Jalan Blangbintang Lama, Lampoh Keude, Kuta Baro, Kabupaten Aceh Besar \\ 2Akademi Komunitas Negeri Aceh Barat \\ Jalan Ikandar Muda, Komplek STTU Alue Peunyareng, Ujong Tanoh Darat, Meureubo \\ Email; rahmad.nuthihar@aknacehbarat.ac.id
}

\begin{abstract}
Abstrak - Penelitian ini bertujuan mendeskripsikan jenis dan fungsi tindak tutur direktif yang digunakan pedagang asongan pada Kapal Motor Penyeberangan (KMP) di Pelabuhan Ulee Lheue Banda Aceh dalam interaksinya dengan pembeli. Penelitian ini termasuk jenis penelitian kualitatif dengan menggunakan pendekatan deskriptif-kualitatif. Pengumpulan data dilakukan dengan teknik rekam dan catat. Data diolah dengan langkah mengidentifikasi data, mengklasifikasi data, menganalisis data, dan menyimpulkan. Hasil penelitian menunjukkan bahwa, (1) Jenis tindak tutur direktif yang terdapat pada interaksi jual-beli pedagang asongan pada Kapal Motor Penyeberangan (KMP) di Pelabuhan Ulee Lheue Banda Aceh meliputi: jenis pertanyaan (questions), permintaan (requstives), larangan (prohibitive), pemberian izin (permissives), desakan dan saran, (2) Fungsi tindak tutur direktif yang ditemukan dalam interaksi jual-beli pedagang asongan pada Kapal Motor Penyeberangan (KMP) di Pelabuhan Ulee Lheue Banda Aceh sebanyak enam fungsi tindak tutur direktif. Fungsi tindak tutur direktif yang ditemukan dalam penelitian ini meliputi: delapan fungsi bertanya, satu fungsi memohon, dua fungsi melarang, tiga fungsi mendesak, satu fungsi membolehkan, dan dua fungsi menyarankan.
\end{abstract}

Kata Kunci: Tindak Tutur Direktif, Interaksi Jual Beli.

Abstract-This study aims to describe the type and function of directive speech acts used by hawkers in Motorized Crossing Ships (KMP) in Ulee Lheue Port, Banda Aceh, in their interactions with buyers. This research includes the type of qualitative research using a descriptive-qualitative approach. Data collection is done by recording and recording techniques. Data is processed by step identifying data, classifying data, analyzing data, and concluding. The results of the study show that, (1) the type of directive speech acts that occur in the interaction of selling and buying peddlers at the Crossing Motorboat (KMP) at Ulee Lheue Port in Banda Aceh include: questions, requests (requstives), prohibitions (prohibitive ), permissives, pressures and suggestions, (2) The directive function of speech acts found in the interaction of the sale and purchase of hawkers at the Crossing Motorboat (KMP) at Ulee Lheue Port in Banda Aceh is six directive speech acts. The directive speech act functions found in this study include: eight question functions, one invoking function, two prohibiting functions, three urgent functions, one function allows, and two functions suggest.

Keywords: Directive Speech, Buy and Sell Interactions.

\section{PENDAHULUAN}

Penelitian ini berkenaan dengan tindak tutur direktif pedagang asongan pada Kapal Motor Penyeberangan (KMP) di Pelabuhan Ulee Lheue Banda Aceh. Yule (2006:82) mengungkapkan bahwa tindak tutur merupakan suatu tindakan yang ditampilkan melalui ujaran dalam proses komunikasi. Dengan kata lain, tindak tutur merupakan suatu interaksi yang dilakukan dalam proses berkomunikasi melalui tuturan.

Tindak tutur yang akan diteliti dalam penelitian ini adalah jenis tindak tutur direktif. Ardianto (2013:2) dalam penelitiannya mengatakan bahwa tindak tutur direktif adalah tindak tutur yang dilakukan penutur dengan tujuan menghasilkan efek berupa tindakan yang dilakukan oleh penutur. Tindak tutur direktif juga dapat diartikan sebagai tindak tutur yang digunakan oleh penutur untuk memerintahkan mitra tuturnya melakukan apa yang diinginkan oleh penutur, Erlis (2014:1). Berdasarkan beberapa pendapat di atas, dapat disimpulkan bahwa tindak tutur direktif dianggap sebagai tindak tutur yang dimaksudkan agar penutur melakukan suatu tindakan sebagaimana yang diinginkan oleh penutur melalui ujarannya. Tuturan-tuturan yang dimaksud dapat berupa memaksa, memohon, menyarankan, meminta, mendesak, menyuruh, dan sejenisnya.

Tindak tutur dapat ditemui di mana saja dan dilakukan oleh siapa saja, tak terkecuali pada pedagang asongan. Salah satu contoh tindak tutur yang diucapkan pedagang asongan ketika berinteraksi dengan pembeli yaitu "Aqua aqua... kacang... telur puyuh. Aquanya Bu?” Tuturan tersebut termasuk ke dalam tindak tutur direktif jenis bertanya. Dalam tuturan tersebut penutur yang bertindak sebagai pedagang bertanya kepada lawan tutur sebagai pembeli apakah pembeli tersebut mau membeli dagangan yang ditawarkan. Hal tersebut dapat dilihat dari kata "Aquanya Bu?" 
Penelitian tentang tindak tutur sudah pernah dilakukan oleh beberapa peneliti lainnya, seperti Erlis, dkk. (2014), Nurhasanah (2017), Ilmiah dan Affandy (2017), Ardianto (2013). Hasil penelitian Erlis, dkk (2014) dalam penelitiannya terhadap tindak tutur guru menyimpulkan bahwa Guru MTsN Lubuk Buaya lebih sering menggunakan bentuk tindak tutur direktif pertanyaan dalam menyampaikan materi pada kegiatan latihan berbicara dibandingkan dengan bentuk lainnya. Guru lebih cenderung menuntut siswa untuk melakukan sesuatu dengan bertanya. Jarang sekali guru menggunakan bentuk tindak tutur direktif melarang. Sementara itu, Nurhasanah (2017) dalam penelitiannya mengenai tindak tutur direktif pada upacara lamaran masyarakat Lampung menyimpulkan bahwa dalam upacara lamaran masyarakat Lampung Komering, ditemukan empat jenis tindak tutur direktif. Keempat jenis tindak tutur direktif tersebut adalah tindak tutur direktif permintaan/permohonan, tindak tutur direktif harapan/keinginan, tindak tutur direktif nasihat, dan tindak tutur direktif perintah. Hal tersebut tidak jauh berbeda dengan hasil penelitian oleh Ilmiah dan Affandy (2017) mengenai tindak tutur direktif kampanye calon Gubernur DKI Jakarta yaitu pertama, terdapat enam jenis tindak tutur direktif kampanye pada calon gubernur DKI Jakarta 2016. Jenis tersebut meliputi tindak meminta, pertanyaan, perintah, melarang, mengabulkan dan tindak nasihat. Kedua, terdapat 19 fungsi tindak tutur direktif kampanye calon gubernur DKI Jakarta 2016. Fungsi tersebut meliputi fungsi memohon, menekan, mengundang, mengajak, berdoa, menginterogasi, bertanya, menghendaki, mengarahkan, menginstruksi, mengatur, mensyaratkan, melarang, menyetujui, memberi wewenang, mengizinkan, menasihatkan, mengusulkan, dan fungsi mengarahkan.

Berkaitan dengan hal di atas, Ardianto (2013) dalam penelitiannya tentang tindak tutur direktif guru dalam wacana interaksi kelas anak tunarungu menyimpulkan bahwa pertama, bentuk tindak tutur direktif meliputi bentuk deklaratif, interogatif, dan imperatif. Kedua, fungsi tindak tutur direktif meliputi fungsi memerintah, meminta, melarang, mengizinkan, menyarankan, mengharapkan, mengajak, menegur, dan memancing. Ketiga, strategi tindak tutur direktif meliputi strategi langsung dan strategi tidak langsung. Realisasi bentuk, fungsi, dan strategi tindak tutur direktif oleh guru berdasarkan keragaman konteks yang melatari wacana percakapan di kelas.

Peneliti tertarik melakukan penelitian ini karena pedagang asongan menggunakan tuturannya untuk memancing respons pembeli agar pembeli tertarik dan mau membeli dagangannya. Berbeda dengan tindak tutur yang digunakan oleh guru, guru menggunakan tuturannya untuk memancing respons siswa agar melakukan hal yang dikehendaki guru dalam proses belajar mengajar.

Berdasarkan uraian di atas, penelitian ini akan mengkaji tindak tutur direktif pedagang asongan pada Kapal Motor Penyeberangan (KMP) di Pelabuhan Ulee Lheue Banda Aceh dalam interaksinya dengan pembeli.

\section{METODE PENELITIAN}

Jenis penelitian ini adalah kualitatif dengan pendekatan deskriptif-kualitatif. Mahsun (2006:233) mengatakan bahwa penelitian deskriptif fokusnya pada penunjukan makna, deskripsi, penjernihan, dan penempatan data pada konteksnya masing-masing dan data tersebut dalam bentuk kata-kata. Penelitian ini dilakukan di Kapal Motor Penyeberangan (KMP) Pelabuhan Ulee Lheue Banda Aceh.
KMP BRR dijadikan sebagai tempat penelitian karena KMP BRR merupakan tempat para pedagang asongan melakukan interaksi jual beli sehingga dapat membantu peneliti menemukan data.

Sumber data penetian ini adalah pedagang asongan pada Kapal Motor Penyeberangan di Pelabuhan Ulee Lheue Banda Aceh. Data dalam Penelitian ini adalah tindak tutur direktif pedagang asongan pada Kapal Motor Penyeberangan di Pelabuhan Ulee Lheue Banda Aceh dalam interaksinya dengan para pembeli. Pengumpulan data dilakukan dengan metode simak. Menurut Silalahi (2009:198), penggunaan metode simak ini sama halnya dengan metode observasi, yaitu, kegiatan keseharian manusia dengan menggunakan pancaindera mata sebagai alat bantu utamanya selain pancaindera lainnya, seperti telinga, penciuman, mulut, dan kulit. Dalam melakukan penyimakan, peneliti menggunakan alat perekam (voice recorder) untuk memudahkan tahap pencatatan ke dalam kartu data.

\section{HASIL PENELITIAN}

Data-data yang diperoleh dan dibahas dalam penelitian ini adalah tindak tutur direktif yang dilakukan dalam interaksi jual-beli pedagang asongan pada Kapal Motor Penyeberangan (KMP) di Pelabuhan Ulee Lheue Banda Aceh. Pembagian jenis tindak tutur dalam penelitian ini berdasarkan klasifikasi yang dikemukakan oleh Ibrahim (1993:27). Ibrahim membagi tindak tutur direktif menjadi 6 (enam) jenis yaitu: permintaan (requstives), pertanyaan (questions), perintah (requirements), larangan (prohibitive), pemberian izin (permissives), dan nasihat (advisories). Sementara Searle (dalam Rohmadi, 2004:32 dan Rustono, 1999:39) membagi tindak tutur direktif atas 12 (dua belas) jenis, yaitu permintaan, ajakan, paksaan, saran, desakan, suruhan, tagihan, perintah, permohonan, tantangan, pemberian aba-aba. Dari beberapa jenis tindak tutur direktif tersebut, tindak tutur direktif jenis pertanyaan memiliki jumlah paling banyak. Kemudian disusul dengan jenis desakan, saran, larangan, permintaan, dan pemberian izin.

Berdasarkan penggolongan fungsi tindak tutur yang dikemukakan oleh beberapa ahli, salah satunya Ibrahim (1993: 27), dalam penelitian ini ditemukan enam fungsi tindak tutur direktif. Kategori fungsi bertanya merupakan fungsi yang paling banyak ditemukan. Fungsi selanjutnya yaitu fungsi mendesak, fungsi melarang, fungsi meyarankan, fungsi membolehkan, dan fungsi memohon.

Fungsi tindak tutur yang ditemukan dalam penelitian ini meliputi delapan tuturan bertanya, tiga tuturan mendesak, dua tuturan melarang, dua tuturan menyarankan, satu tuturan memohon, dan satu tuturan membolehkan.

Hasil penelitian menunjukkan bahwa dalam interaksi jual-beli pedagang asongan pada Kapal Motor Penyeberangan (KMP) di Pelabuhan Ulee Lheue Banda Aceh ditemukan enam jenis tindak tutur direktif dan enam fungsi tindak tutur direktif. Berikut ini akan dibahas mengenai jenis dan fungsi tindak tutur direktif yang ditemukan dalam interaksi jual beli pedagang asongan pada Kapal Motor Penyeberangan (KMP) di Pelabuhan Ulee Lheue Banda Aceh.

\section{Pertanyaan (Questions)}

Tindak bertanya mengandung pengertian bahwa dalam mengucapkan suatu tuturan, penutur menanyakan sesuatu 
pada lawan tutur dan mengkehendaki lawan tuturnya melakukan sesuatu yang dikehendakinya sesuai dengan tuturan yang diucapkan. Berdasarkan ciri formalnya pola intonasi kalimat tanya ditandai dengan tanda tanya (?). Tindak tutur direktif jenis pertanyaan dapat dilihat pada data berikut.

(1) PJ: Buahnya, Buk? Apel, Anggur, 15 ribu.

Konteks: Pedagang berjalan berkeliling kapal menjajakan dagangannya kepada pembeli sambil bertanya apakah mungkin ada pembeli yang ingin membeli dagangannya.

Tuturan pada data (1) tersebut merupakan interaksi yang terjadi antara penjual dan pembeli. Pada tuturan tersebut pedagang yang menjual buah mengatakan harga buah yang dijualnya sambil bertanya pada pembeli apakah pembeli tersebut mau membeli dagangannya.

\section{(2) PJ: Salak, Pak?}

Konteks: Pedagang berjalan berkeliling kapal menjajakan dagangannya kepada pembeli sambil bertanya apakah mungkin ada pembeli yang ingin membeli dagangannya.

Tuturan pada data (2) memiliki konteks dan maksud yang sama dengan data (1). Pada tuturan tersebut menawarkan dagangannya dan bertanya apakah pembeli mau membeli dagangannya.

\section{(3) PJ: Buahnya, siapa lagi?}

Konteks: Pedagang buah berteriak menawarkan dagangannya kepada pembeli, kemudian salah satu pembeli memanggil dan membeli dagangannya. Setelah itu pembeli bertanya kepada pembeli lainnya.

Pada data (3) terjadi interaksi antara pedagang dan pembeli. Pedagang yang dagangannya baru saja dibeli oleh salah satu pembeli tersebut kemudian bertanya pada pembeli lain siapa yang mau membeli dagangannya lagi.

\section{Permintaan (Requestives)}

Tindak meminta menunjukkan dalam pengucapan sesuatu tuturan, penutur memohon kepada mitra tutur untuk melakukan suatu perbuatan. Penutur mengekspresikan keinginan dan maksud agar lawan tutur melakukan tindakan atas apa yang diinginkan penutur. Dengan kata lain tindak tutur ini mengekspresikan keinginan penutur, sehingga lawan tutur melakukan sesuatu. Tindak tutur permintaan dapat dilihat pada data berikut.

(4) PJ: Udah ada nasi, Dek? Belilah satu.

Konteks: Pedagang yang merupakan penjual nasi menawarkan dagangannya kepada pembeli.

Tuturan pada data (4) mengekspresikan keinginan penutur agar pembeli tersebut mau membeli dagangannya. Penutur menawarkan dagangannya dengan ekspresi sungguh-sungguh dan meminta agar pembeli tersebut melakukan sesuatu yang diinginkan oleh pedagang.

\section{Larangan (Prohibitive)}

Tindak larangan merupakan suatu tindakan yang menunjukkan bahwa ketika mengucapkan suatu ekspresi penutur melarang lawan tutur untuk melakukan tindakan. Penutur mengekspresikan otoritas kepercayaan bahwa ujarannya menunjukan alasan yang cukup bagi lawan tutur untuk tidak melakukan tindakan. Tindak tutur larangan dapat dilihat pada data berikut.

(5) PJ: Gak bisa Buk. Memang mahal kami belinya. Jualan aja sekarang gak bisa tiap hari karena sering gak laku.

Konteks: Interaksi antara seorang pedagang dan pembeli yang berniat membeli dagangannya dan berusaha menawar harga yang disebutkan oleh pedagang.

Tuturan pada data (5) mengekspresikan maksud pedagang yang menolak dan melarang pembeli untuk menawar harga dagangannya. Pedagang tersebut mengatakan bahwa harga dagangannya tidak bisa ditawar lagi karena harga tersebut sesuai dengan modal yang ia keluarkan

(6) PJ: Janganlah Pak. Ini udah murah saya jual.

Konteks: Seorang pedagang yang menolak dagangannya ditawar dengan harga yang lebih murah dari harga yang ditetapkannya.

Pada data (6) terjadi interaksi antara pembeli dan pembeli. Dalam tuturan tersebut pedagang mengatakan ketidaksetujuannya terhadap harga yang ditawar oleh pembeli. Melalui tuturan tersebut pedagang mengekspresikan maksud tuturannya agar pembeli tersebut mengerti dan melakukan apa yang dikehendaki oleh pedagang tersebut yaitu agar pembeli mau membeli dagangannya dengan harga yan sudah ditetapkan olehnya dan tidak menawar dengan harga yang lebih murah.

\section{Desakan}

Tindak tutur desakan adalah tindak tutur yang disampaikan penutur dengan cara memaksa mitra tutur agar segera melakukan sesuatu sesuai kehendak penutur. Tindak tutur mendesak dapat dilihat pada data berikut.

(7) PJ: Ambil satu Kak buahnya? Ambillah...

Jeruk kalo ambil dua boleh 25 ribu.

Konteks: Pedagang menawarkan dagangannya kepada pembeli. Saat pedagang berjualan, situasi sedang sepi pembeli.

Tuturan pada data (12) merupakan tuturan yang terjadi antara pedagang dan pembeli. Pedagang berbicara menawarkan dagangannya kepada salah satu pembeli dengan cara sedikit mendesak. Hal tersebut dimaksudkan oleh penutur yaitu pedagang agar lawan tutur atau pembeli melakukan sesuatu yang dikehendaki oleh penutur tersebut yaitu agar pembeli membeli dagangannya.

(8) PJ: Salak 10 ribu...

$N i$ enak Buk salaknya manis bukan kayak salak biasa.

Konteks: Pedagang buah menawarkan dagangannya kepada pembeli saat situasi sedang sepi pembeli.

Tuturan yang terdapat pada data (8) mengandung maksud penutur yang bertindak sebagai pedagang yang mengkehendaki lawan tuturnya yaitu pembeli untuk segera membeli dagangannya. Pada tuturan tersebut pedagang juga mengatakan atau menjelaskan keunggulan dari dagangannya. Hal itu dilakukan agar pembeli tertarik dan membeli dagangannya sesuai dengan yang dikehendaki oleh penutur atau pedagang tersebut. 


\section{Pemberian Izin (Permissives)}

Tindak pemberian izin merupakan tindakan yang menerangkan bahwa ketika mengucapkan suatu tuturan menghendaki lawan tutur untuk melakukan perbuatan (tindakan). Dengan kata lain, tindak tutur ini mengekspresikan kepercayaan penutur dan maksud penutur, sehingga mitra tutur percaya bahwa ujaran penutur mengandung alasan yang cukup bagi lawan tutur untuk merasa bebas melakukan sesuatu. Tindak tutur pemberian izin dapat dilihat pada data berikut.

(9) PB: Ambil dua, 25 ribu boleh?

PJ: Ya, udah. Bolehlah. Jeruk aja Buk?

Konteks: Pembeli berusaha menawar dengan harga yang lebih murah dari harga yang ditetapkan oleh pedagang. Interaksi yang terjadi pada data (15) terjadi antara pedagang dan pembeli. Dalam tuturan tersebut pedagang menuturkan tuturan yang mengandung maksud memperbolehkan atau menyetujui tuturan yang dituturkan oleh pembeli.

\section{Saran}

Tindak tutur menyarankan merupakan tindakan penutur dalam mengujarkan sesuatu dengan tujuan memberitahukan kepada mitra tutur agar mau mengikuti saran yang diberikan oleh penutur dan mempertimbangkannya. Tindak tutur menyarankan dapat dilihat pada data berikut.

(10) PJ: Gak ada kembalian uang seribu. Ambil kacang aja satu lagi.

Konteks: Salah satu pedagang ingin mengembalikan uang kembalian kepada salah satu pembeli namun ia tidak memiliki pecahan uang yang diinginkan.

Interaksi yang terjadi pada data (16) terjadi antara pedagang dan pembeli. Dalam tuturan tersebut pedagang menuturkan tuturan yang memiliki maksud menawarkan atau menyarankan pembeli untuk melakukan apa yang dikehendakinya yaitu menyarankan pembeli mengambil barang yang dijualnya sesuai dengan harga atau uang yang seharusnya ia kembalikan kepada pembeli tersebut.

(11) PB: Ada jual sirih, Pak?

PJ: Gak ada Pak, coba tanya sama Abang itu.

Konteks: Pembeli bertanya kepada pedagang apakah pembeli tersebut menjual barang atau sesuatu yang dimaksud oleh pembeli tersebut.

Dalam tuturan pada data (11) pedagang mengatakan kepada pembeli bahwa ia tidak menjual sesuatu yang dimaksud oleh pembeli, pedagang tersebut juga menyarankan pembeli tersebut untuk menanyakan kepada pedagang lain mungkin mereka menjual barang atau sesuatu yang dimaksud oleh pembeli tersebut.

\section{KESIMPULAN}

Berdasarkan hasil penelitian dan pembahasan yang telah dituliskan dapat disimpulkan bahwa jenis tindak tutur direktif yang terdapat pada interaksi jual beli pedagang asongan pada Kapal Motor Penyeberangan (KMP) di Pelabuhan Ulee Lheue Banda Aceh meliputi: jenis pertanyaan (questions), permintaan (requstives), larangan (prohibitive), pemberian izin (permissives), desakan dan saran. Selanjutnya, fungsi tindak tutur direktif yang ditemukan dalam interaksi jual beli pedagang asongan pada Kapal Motor Penyeberangan (KMP) di Pelabuhan Ulee Lheue Banda Aceh sebanyak enam fungsi tindak tutur direktif. Fungsi tindak tutur direktif yang ditemukan dalam penelitian ini meliputi: delapan fungsi bertanya, satu fungsi memohon, dua fungsi melarang, tiga fungsi mendesak, satu fungsi membolehkan, dan dua fungsi menyarankan.

\section{REFERENS}

[1] Yule, George. 2006. Pragmatik (Terjemahan Indah Fajar Wahyuni). Yogyakarta: Pustaka Pelajar.

[2] Ardianto. 2013. "Tindak Tutur Direktif Guru dalam Wacana Interaksi Kelas Anak Tunarungu". Litera. Vol 12, No.1, 1011

[3] Erlis, Erlina., dkk. 2014. "Tindak Tutur Direktif Guru dalam Kegiatan Muhadarah di MTsn Lubuk Buaya Kota Padang". Jurnal Bahasa, Sastra, dan Pembelajaran. Vol 2, No.3, 67-68.

[4] Ilmiah, N., \& Affandy, A. N. (2018). "Tindak Tutur Direktif Kampanye Calon Gubernur DKI Jakarta 2016". Stilistika Jurnal Pendidikan Bahasa Dan Sastra. Vol 10, No.2, 114

[5] Mahsun. 2006. Metode Penelitian Bahasa. Jakarta: PT Raja Grafindo Persada.

[6] Silalahi, Uber. 2009. Metode Penelitian Sosial. Bandung: PT Refika Aditama.

[7] Rohmadi, Muhammad. 2004. Pragmatik: Teori dan Analisis. Yogyakarta: Lingkar Media.

[8] Rusminto, Nurlaksana Eko. 2015. Analisis Wacana: Kajian Teoritis dan Praktis. Bandarlampung: Universitas Lampung.

[9] Nuthihar, Rahmad. 2018. "Karakteristik Tindak Tutur dalam Persidangan di Pengadilan Negeri Banda Aceh". Tesis. FKIP: Universitas Syiah Kuala 